\title{
PERBANDINGAN LAMA PEMBERIAN INDUKSI ANTARA INDUKSI MISOPROSTOL PER ORAL DAN BALON KATETER PADA KEHAMILAN POSTMATUR DI RSUD WATES
}

\author{
Komalasari ${ }^{1}$ \\ jasmine.komala@gmail.com \\ ${ }^{1}$ Akademi Kebidanan Alifa Pringsewu, Jalan Jend. A. Yani Gang Gunungsari No 5. Sidoharjo, \\ Pringsewu, Lampung 35373, Indonesia Telp (0729) 22479
}

\begin{abstract}
Abstrak
Upaya induksi persalinan adalah prosedur umum yang digunakan pada praktik kebidanan secara luas di seluruh dunia. Semua kehamilan akan menuju pada suatu keadaan aterm dan proses persalinan akan berlangsung secara spontan. Kenyataannya ada beberapa keadaan yang mengharuskan untuk mempercepat proses persalinan dengan mempertimbangkan keadaan ibu dan janin. Kehamilan postmatur adalah salah satu indikasi dilakukannya induksi persalinan. Meskipun di RSUD Wates sudah ditetapkan protap mengenai induksi persalinan, tetapi penggunaan jenis induksi masih beragam antara misoprostol per oral dan balon kateter dan sampai saat ini belum diperoleh metode induksi yang efektif dalam hal waktu.Tujuan penelitian untuk membandingkan lama pemberian induksi antara misoprostol per oral dan balon kateter pada kehamilan postmatur. Metode penelitian ini merupakan penelitian analitik observasional dengan desain historical cohort. Sampelnya adalah ibu hamil postmatur di RSUD Wates dengan induksi persalinan yang memenuhi kriteria inklusi dan eksklusi. Jumlah sampel pada kelompok terpapar (misoprostol per oral) dan kelompok tidak terpapar (balon kateter) masing-masing 16 orang. Instrumen penelitian adalah peneliti dan lembar format pengumpulan data. Analisis untuk uji hipotesis dilakukan dengan uji independent sampel t-test dengan $\mathrm{p}<0,05$ dan Interval Kepercayaan 95\%. Hasil Lama waktu pemberian induksi sampai pembukaan lengkap dengan misoprostol per oral dan balon kateter sebesar 626,87 menit dan 719,31 menit. Terdapat perbedaan lama pemberian induksi misoprostol per oral dan balon kateter sebesar 92,44 menit, dimana kelompok induksi misoprostol per oral 92,44 menit lebih cepat dibanding kelompok induksi balon kateter. Hasil ini bermakna secara statistik dengan pvalue $0,001<0,05$ dan CI 95\% (37,73 - 147,14).Kesimpulan lama pemberian induksi sampai pembukaan lengkap dengan misoprostol per oral lebih cepat dibandingkan dengan balon kateter pada kehamilan postmatur.
\end{abstract}

Kata Kunci : Lama pemberian induksi, jenis induksi, kehamilan postmatur .

\section{Pendahuluan}

Menurut Alarm Internasional upaya induksi persalinan adalah prosedur umum yang digunakan pada praktik kebidanan secara luas di seluruh dunia. Semua kehamilan akan menuju pada suatu keadaan aterm dan proses persalinan akan berlangsung secara spontan. Kenyataannya ada beberapa keadaan yang mengharuskan untuk mempercepat proses persalinan dengan mempertimbangkan keadaan ibu dan janin $^{1,2}$.

Indikasi dilakukan induksi antara lain: hamil postmatur (lebih dari 41 minggu), ketuban pecah dini, janin mati dalam kandungan, preeklamsi berat yang tidak membaik. Kontra indikasi induksi dibagi dua yaitu; absolute: disproporsi kepala panggul, plasenta previa totalis / letak rendah di belakang, gawat janin, uterus cacat (pasca secsio caesarea yang tidak diketahui jenisnya) dan relative: grande multigravida, kelainan letak presentasi, overdistensi uterus, presentasi bokong murni, pasca secsio caesarea kurang dari 2 tahun $^{3}$.

Ibu dengan kehamilan 41 - 42 minggu harus ditawarkan untuk dilakukan induksi persalinan dan telah diketahui adanya bukti penurunan dalam kematian perinatal tanpa meningkatkan risiko sectio caesarea (Evidence quality $A$ ). Sebuah review telah menilai efektivitas dan keamanan misoprostol per oral untuk menginduksi persalinan pada wanita dengan janin hidup di trimester ketiga kehamilan. Penggunaan misoprostol mengakibatkan beberapa efek samping, namun efek samping yang bermakna tidak ditemukan pada bidang hematologi, endokrin, biokimia, imunologi, 
oftalmologi, respiratorik, kardiovaskular maupun faktor pembekuan darah ${ }^{4,5,6}$.

Di negara berkembang, tindakan pematangan serviks yang sering dilakukan adalah dengan pemakaian balon kateter intraservikal. Metode ini mudah dilakukan dan murah biayanya. Teknik ini telah terbukti aman, efektif dan tidak mahal serta kemungkinan terjadinya infeksi tidak lebih besar dari angka kejadian infeksi di rumah sakit jika tindakan aseptik dilakukan. Cromi dkk melakukan penelitian terhadap 602 wanita yang menggunakan balon kateter dalam pematangan serviks dalam rangka induksi persalinan, diperoleh bahwa balon kateter aman digunakan untuk pematangan serviks tanpa peningkatan resiko infeksi pada ibu dan bayi ${ }^{7}$.

Antara kedua kelompok induksi tersebut, telah terbukti bahwa pada pasien dengan induksi misoprostol terjadi pelepasan prostaglandin yang lebih banyak dibandingkan dengan metode mekanik seperti balon kateter. Prostaglandin yang meningkat akan berakibat meningkatkan kontraksi uterus menjadi lebih kuat. Kontraksi uterus atau his yang lebih kuat ini akan memberikan efek proses pembukaan serviks terjadi lebih cepat sampai pembukaan serviks maksimal $(10 \mathrm{~cm})$ sehingga didapatkan waktu persalinan yang lebih cepat ${ }^{8}$.

Berdasarkan uraian di atas, penulis tertarik untuk melakukan penelitian di RSUD Wates tahun 2012 dengan judul perbandingan lama pemberian induksi antara induksi misoprostol per oral dan balon kateter pada kehamilan postmatur.

\section{Metode Penelitian}

Penelitian ini merupakan jenis penelitian observasional analitik dengan desain penelitian study historical cohort 9 , 10 . Variabel bebas pada penelitan ini adalah jenis induksi yang menggunakan skala data nominal. kelompok pertama yaitu induksi misoprostol per oral. Induksi misoprostol per oral adalah induksi menggunakan tablet pil dengan dosis $25 \mu \mathrm{g}$ diminum per oral oleh pasien, dievaluasi setiap 6 jam sampai pasien masuk dalam kala II persalinan. Kelompok kedua yaitu induksi balon kateter. Induksi balon kateter adalah foley kateter dengan balon kecil di ujungnya yang terbuat dari karet (lateks) yang diinsersikan lewat kanalis servikalis melalui orifisium uteri internum dan ditambahkan dengan aqua dess $50 \mathrm{cc}$. Kateter akan terlepas sendiri jika sudah masuk fase aktif persalinan. Variabel terikat dalam penelitian ini adalah lama pemberian induksi yaitu rentang waktu yang dihitung sejak pemberian induksi yang menyebabkan perubahan pada serviks (membuka dan menipis) dan berakhir dengan pembukaan lengkap dihitung dalam satuan menit. Skala pengukuran menggunakan data rasio. Penelitian dilakukan di Rumah Sakit Umum Daerah Wates Kulon Progo, Provinsi Daerah Istimewa Yogyakarta. Populasi dalam penelitian ini adalah seluruh ibu hamil postmatur dari Januari 2012 sampai Desember 2012. Pengambilan sampel dalam penelitian ini menggunakan teknik purposive sampling dengan kriteria inklusi dan eksklusi. Jumlah sampel yang dibutuhkan berdasarkan rumus penghitungan besar sampel independen dengan perbedaan mean, didapatkan kelompok pertama 16 sampel dengan induksi misoprostol per oral dan 16 sampel dengan induksi balon kateter sebagai kelompok kedua.

Jenis data yang digunakan adalah data sekunder sehingga proses pengambilan sampel dilakukan dengan melihat catatan atau register ibu bersalin di ruang bersalin RSUD Wates Kulon Progo. Teknik pengolahan data dilakukan dengan editing, coding, dan entry data dan tabulating. Penelitian ini menggunakan analisis univariat dan bivariat dengan uji independent sample t-test menggunakan program R 2.9.0 OS Windows. Dengan interpretasi hasil; apabila nilai $\rho$ - value < 0,05 menunjukkan bahwa terdapat perbedaan antara induksi misoprostol per oral dan balon kateter. Kemudian apabila nilai $\rho$-value $>0,05$ menunjukkan bahwa tidak terdapat perbedaan antara induksi misoprostol per oral dan balon 6 kateter ${ }^{11,12}$.

\section{Hasil dan Pembahasan}

Karakteristik subjek yang diamati dalam penelitian ini adalah umur dan paritas yang disajikan dalam tabel berikut: 
Tabel 1 Karakteristik Responden

\begin{tabular}{lccc}
\hline Karakteristik & \multicolumn{2}{c}{ Jenis Induksi } & $\begin{array}{c}\text { P- } \\
\text { value }\end{array}$ \\
\cline { 2 - 3 } & $\begin{array}{c}\text { Misoprostol } \\
\text { per Oral }\end{array}$ & $\begin{array}{c}\text { Balon } \\
\text { Kateter }\end{array}$ & \\
\hline Usia & & & \\
Beresiko (<20 & & & \\
th \& $>35$ th) & 2 & 14 & \\
$\begin{array}{l}. \text { Tidak Beresiko } \\
\text { (20-35 th) }\end{array}$ & 14 & & \\
& & & \\
Paritas & & & \\
Beresiko (<20 \\
th \& $>35$ th)
\end{tabular}

Berdasarkan Tabel 1. di atas dapat diketahui bahwa tidak ada perbedaan yang bermakna secara statistik mengenai usia ibu pada induksi misoprostol per oral dan balon kateter dengan $p$-value $0,59>0,05$. Begitu juga dengan paritas ibu, tidak ada perbedaan yang bermakna antara paritas pada induksi misoprostol per oral dan balon kateter dengan $\mathrm{p}$-value $1>0,05$. Sehingga karakteristik usia dan paritas disini samasama tidak berpengaruh terhadap lama pemberian induksi pada kehamilan postmatur.

Sebelum dilakukan uji beda 2 sampel independen dengan menggunakan rumus Independent T-Test, terlebih dahulu dilakukan uji persyaratan analisis, yaitu uji normalitas sebaran dan uji homogenitas varians. hasil uji normalitas dengan kolmogorov-Smirnov didapatkan nilai $\rho$. value untuk lama pemberian induksi pada misprostol per oral adalah sebesar 0,96 dan pada balon kateter sebesar 0,72 yang artinya nilai $\rho$ - value $>0,05$ sehingga dapat disimpulkan bahwa data mempunyai sebaran (distribusi) normal.

Uji homogenitas pada lama pemberian induksi diperoleh nilai $\rho_{\text {- value sebesar } 0,06}$ $>0,05$ sehingga dapat disimpulkan bahwa homogenitas data terpenuhi. Karena data berdistribusi normal dan homogen maka dapat dilakukan uji beda menggunakan uji Independent sample t-test. Berikut adalah tabel hasil perhitungan beda rata-rata lama pemberian induksi antara induksi misoprostol per oral dan balon kateter :
Tabel 2. Perbedaan Lama Pemberian induksi Misoprostol per oral dan Balon Kateter Pada kehamilan Postmatur

\begin{tabular}{|c|c|c|c|c|}
\hline $\begin{array}{c}\text { Jenis } \\
\text { Induksi }\end{array}$ & $\begin{array}{l}\text { Rata-rata } \\
\text { Lama } \\
\text { Pemberian } \\
\text { Induksi }\end{array}$ & $\begin{array}{l}\rho- \\
v a \\
l u \\
e\end{array}$ & $\begin{array}{c}\text { Mea } \\
n \\
\text { Diff } \\
\text { eren } \\
t\end{array}$ & CI $95 \%$ \\
\hline $\begin{array}{l}\text { Misoprostol } \\
\text { per oral }\end{array}$ & 626.87 & \multirow{2}{*}{$\begin{array}{c}0 . \\
00 \\
1\end{array}$} & \multirow{2}{*}{$\begin{array}{c}92.4 \\
4\end{array}$} & \multirow{2}{*}{$\begin{array}{l}37.73: \\
147.14\end{array}$} \\
\hline $\begin{array}{l}\text { Balon } \\
\text { Kateter }\end{array}$ & 719.31 & & & \\
\hline
\end{tabular}

Tabel 2. menunjukkan bahwa rata-rata lama pemberian induksi misoprostol per oral sebesar 626,87 menit. Sedangkan pada induksi balon kateter terdapat rata-rata lama pemberian induksi sebesar 719,31 menit, sehingga ada perbedaan lama pemberian induksi antara induksi misoprostol per oral dan balon kateter sebesar 92,44 menit, dimana kelompok induksi misoprostol per oral 92,44 menit lebih cepat dibanding kelompok induksi balon kateter dan bermakna secara statistik dengan $\rho$-value $0,001<0,05$ dan CI 95\% $(37,73-147,14)$.

Berdasarkan hasil penelitian dan analisis yang telah dilakukan, peneliti telah mengendalikan beberapa faktor yang dapat mempengaruhi lama pemberian induksi persalinan diantaranya usia dan paritas ibu. Faktor usia dibagi menjadi dua kelompok yaitu usia berisiko $(<20$ th $\&>35$ th) dan usia tidak berisiko (20 th -35 th). Sedangkan faktor paritas ibu dibagi menjadi dua kelompok yaitu paritas berisiko $(1 \& \geq$ 4) dan paritas tidak berisiko $(2 \& 3)$.

Hasil ini sejalan dengan penelitian Purnama (2008) baik banyaknya kelompok usia kurang dari 30 tahun maupun lebih dari 30 tahun dan paritas tidak didapatkan adanya perbedaan yang bermakna secara statistik antara kedua kelompok artinya kedua kelompok tersebut sama-sama tidak berpengaruh terhadap lama pemberian induksi ${ }^{13}$.

Pada umur kurang dari 20 tahun dan lebih dari 35 tahun, organ-organ reproduksi belum berfungsi dengan sempurna sehingga bila terjadi kehamilan dan persalinan akan lebih mudah mengalami komplikasi. Selain itu, kekuatan otot-otot perineum dan otototot perut belum bekerja secara optimal 
sehingga sering terjadi persalinan lama atau macet yang memerlukan tindakan seperti bedah sesar sehingga tindakan induksi dikatakan tidak berhasil. Ibu hamil berumur muda juga memiliki kecenderungan perkembangan kejiwaannya belum matang sehingga belum siap menjadi ibu dan menerima kehamilannya di mana hal ini dapat berakibat terjadinya komplikasi obstetri yang dapat meningkatkan angka kematian ibu dan perinata ${ }^{14}$.

Dibandingkan dengan primigravida, induksi pada multipara akan lebih berhasil karena sudah pernah terdapat pembukaan. Adanya elastisitas pada uterus dan jalan lahir akan mengakibatkan berbedanya lama waktu persalinan antara primigravida dan multipara. Persalinan yang pertama sekali biasanya mempunyai risiko relatif tinggi terhadap ibu dan anak, kemudian risiko ini menurun pada paritas kedua dan ketiga, dan akan meningkat lagi pada paritas keempat dan seterusnya ${ }^{15}$.

Analisis akhir untuk menguji hipotesis adanya perbedaan lama pemberian induksi antara misoprostol per oral dan balon kateter pada kehamilan postmatur dilakukan dengan uji independent sampel t-test. Dari 32 subjek kehamilan postmatur yang dilakukan induksi persalinan menggunakan misoprostol per oral dan balon kateter, diperoleh perbedaan rata-rata waktu yang diperlukan mulai induksi sampai terjadinya pembukaan lengkap antara dua kelompok dengan rata-rata waktu masing-masing 626,87 menit dan 719,31 menit dan selisih antara keduanya sekitar 92,44 menit dimana terdapat perbedaan yang bermakna secara statistik dengan $p$-value 0,001 .

Hasil penelitian ini sesuai dengan penelitian Widyantoro (2010) yang menyatakan bahwa lama mulai induksi pada misoprostol dan balon kateter sampai kala dua persalinan lebih pendek yaitu sebesar 481,33 dan 565 menit. Sedangkan dalam hal umur ibu, umur kehamilan, kematangan serviks dan berat badan bayi tidak ditemukan adanya perbedaan yang bermakna $(p \text {-value }>0,05)^{16}$.

Pada penelitian ini, sampel diambil dari populasi yang sama yaitu ibu hamil postmatur. Perbedaan pada hasil penelitian ini disebabkan oleh jenis induksi yang digunakan dan metode atau cara penggunaan antara oral pada misoprostol dan intraservikal pada balon kateter. Konsentrasi dan boavabilitas dari masingmasing obat yang mempengaruhi lama waktu pemberian induksi. Sebagaimana dijelaskan oleh Wing \& Gaffaney (2006) bahwa waktu paruh misoprostol secara oral lebih cepat dapat diabsorbsi dan diubah menjadi metabolisme yang aktif yaitu asam misoprostol yang akan meningkat dengan cepat dan mencapai puncaknya dalam waktu 12 menit serta paruh waktunya 20-30 menit $^{17}$.

Pada penggunaan balon kateter, adanya tekanan mekanis dari balon kateter dapat mengakibatkan terlepasnya selaput ketuban dari segmen bawah rahim (SBR). Sehingga manipulasi ini akan meningkatkan pembentukan prostaglandin. Hal inilah yang menunjukkan bahwa manipulasi dari balon kateter akan mengakibatkan aktifasi dari desidua yang bertugas menginisiasi persalinan ${ }^{3}$.

Dengan perbedaan waktu antara kedua kelompok induksi tersebut, dapat membuktikan bahwa pada pasien dengan induksi misoprostol terjadi pelepasan prostaglandin yang lebih banyak dibandingkan dengan metode mekanik seperti balon kateter. Prostaglandin yang meningkat akan berakibat meningkatkan kontraksi uterus menjadi lebih kuat. Kontraksi uterus atau his yang lebih kuat ini akan memberikan efek proses pembukaan serviks terjadi lebih cepat sampai pembukaan serviks maksimal $(10 \mathrm{~cm})$ sehingga didapatkan waktu persalinan yang lebih cepat ${ }^{18}$.

\section{Kesimpulan}

Lama pemberian induksi sampai pembukaan lengkap dengan misoprostol per oral lebih cepat 92,44 menit dibandingkan dengan balon kateter pada kehamilan postmatur.

\section{Daftar Pustaka}

[1] Alarm International. 2003. A Program to Reduce Maternal Mortality and Morbidity, 2nd edition. Canada. 
[2] Health Technology Assessment Malaysia. 2003. Misoprostol in pregnancy. Dalam: Health technology Assessment Report.

[3] Cunningham FG, et al. 2005. Williams Obstetrics. United States of America: Mcgraw Hill Companies Inc.

[4] WHO. 2008. Reproductive Health Library. WHO

[5] Alfirevic Z, Weeks A. 2008. Oral misoprostol for induction of labour. Cochrane Database Syst Rev.

[6] Program for appropriate technology in health (PATH). 2005. Misoprostol use in obstetrics and gynecology. In: Outlook 2005, 21(4).

[7] Cromi A, Ghezzi F, Tomera A et al. 2007. Cervical Ripening with The Foley Catheter. Int $J$ Gynaecol Obstet.

[8] Nanik, dkk. 2008. Pengaruh amniotomi terhadap lama persalinan dan luaran janin pada induksi persalinan dengan misoprostol. Yogyakarta: Fakultas Kedokteran Universitas Gadjah Mada.

[9] Notoatmodjo, S. 2005. Metodologi Penelitian Kesehatan. Jakarta: Rineka Cipta.

[10] Sastroasmoro, S., \& Ismael, S. 2011. Dasar - Dasar Penelitian Klinis Edisi Ke-4. Jakarta: Sagung Seto.

[11] Fakultas Kedokteran Universitas Indonesia. 2007. Dasardasar Metodologi Klinis. Jakarta: FKUI.

[12] Arikunto, S. 2006. Prosedur Penelitian Suatu Pendekatan Praktik. Jakarta: Rineka Cipta.

[13] Purnama, E. 2008. Perbandingan Efektifitas antara Misoprostol Per Oral dengan Kateter Voley untuk Pematangan Serviks dalam Rangka Induksi Persalinan. Medan: Departemen Obstetri Ginekologi Fakultas Kedokteran Sumatera Utara.
[14] Kusumawati, Y. 2006. Faktor-faktor Risiko yang Berpengaruh Terhadap Persalinan dengan Tindakan (studi kasus di RS. Dr. Moewardi Surakarta). Tesis. Semarang: Program Pascasarjana Magister Epidemiologi UNDIP.

[15] [15] Saifudin AB, 2010. Ilmu Kebidanan Sarwono Prawirohardjo. Jakarta: PT Bina Pustaka Sarwono Prawirohardjo.

[16] [16] Widyantoro, Andrian Eko. 2010. Perbandingan Keefektifan Induksi Balon Kateter dan Misoprostol Dengan Misoprostol Saja Terhadap Keberhasilan Persalinan Pervaginam. Yogyakarta: Fakultas Kedokteran Universitas Gadjah Mada.

[17] Wing DA, Gaffaney CAL. 2006. Vaginal Misoprostol Administration for Cervical Ripening and Labour Induction. Clin Obstet Gynecol Vol 49.

[18] Nanik, dkk. 2008. Pengaruh amniotomi terhadap lama persalinan dan luaran janin pada induksi persalinan dengan misoprostol. Yogyakarta: Fakultas Kedokteran Universitas Gadjah Mada. 